Vukoman Jokanović1,2*, Nenad Bundaleskit, ${ }^{1,3}$, Božana Čolović ${ }^{\text {, Manuela Ferarra }}{ }^{4}$, Bojan Jokanović ${ }^{5}$, Ilija Nasov 6,7

${ }^{1}$ University of Belgrade, Vinca Institute of Nuclear Sciences, Belgrade, Serbia, ${ }^{2}$ ALBOS d.o.o., Belgrade, Serbia, ${ }^{3}$ Universidade Nova de Lisboa, CEFITEC, Departamento de Física, Faculdade de Ciências e Tecnologia, Portugal, ${ }^{4}$ ENEA, Laboratory of Innovative Devices (DTEFSD-DIN), 80055 Portici (NA), Italy, ${ }^{5}$ SGL Carbon, Weisbaden, Germany, ${ }^{6}$ St. Cyril and Methodius University, Institute of Physics, Faculty for Natural Sciences and Mathematics, Skopje, Republic of North Macedonia, ${ }^{7}$ Plasma Doo, Skopje, Republic of North Macedonia
Scientific paper ISSN 0351-9465, E-ISSN 2466-2585 UDC: $539.23:: 661.882-024$ doi: $10.5937 /$ zasmat2101041J

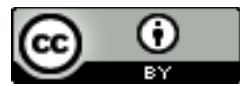

Zastita Materijala 62 (1) $41-50$ (2021)

\title{
Detailed characterization of the Ti-O based thin films obtained by cathodic arc evaporation
}

\begin{abstract}
Physicochemical properties of thin films on the base of titanium oxides, obtained by a cathodic arc evaporation on the surface of glass substrate are analysed in details. The analysis of these films was made by using XRD, FTIR, SEM, XPS analysis and ellipsometry. On the basis of these analyses, particularly analysis obtained by XPS, the oxidative state Ti and corresponding phases are determined through various film layers from the surface to the substrate. The depth of the various levels and their extinction coefficients and refractory indexes are estimated by ellipsometry.
\end{abstract}

Keywords: titanium oxide thin films; XRD; FTIR; SEM; XPS; ellipsometry

\section{INTRODUCTION}

The electronic spectra of titanium suboxides and oxidesare consisted mainly from of four lines (two doublets). The first doublet belongs to the $\mathrm{Ti}_{3}$ edge and the second to the $\mathrm{Ti} L_{2}$ edge. These two doublets can be further splited, inducing the appearence of the many additional peaks dependent on valence state, coordination and site symmetry of the Ti atoms (Leapman et al. 1982; Brydson et al. 1989) [1,2].In the case of the rutile and anatase with titanium oxidative state $\mathrm{Ti}^{4+}$, an additional pre-peak appears just in front of the first $L_{3}$ peak, while the second line of the $L_{3}$ edge is split into two smaller peaks. The spectrum of the pure $\mathrm{Ti}^{3+}$ oxide $\left(\mathrm{Ti}_{2} \mathrm{O}_{3}\right)$ does not exibit any additional peaks, showing that the first lines in the $L_{3}$ and $L_{2}$ edges are distinctly less intense than the second peaks. This effect is even more pronounced in the spectrum of $\mathrm{Ti}^{2+}$ in $\mathrm{TiO}$, showing two main broad $L_{3}$ and $L_{2}$ lines preceded by two negligible pre-peaks.

*Corresponding author: Vukoman Jokanović

E-mail: vukoman@vinca.rs

Paper received: 22. 11. 2020.

Paper accepted: 10. 12. 2020.

Paper is available on the website: www.idk.org.rs/journal
A comparison of the obtained $\mathrm{Ti}_{L 3,2}$ spectra of Ti oxides shows that the $L_{3,2}$ begenning shifts to lower energy with decreasing oxidation state. The shift is about 1.7-2.0 eV per oxidation state. The energy positions of the $\mathrm{Ti}_{L 3,2}$ peaks of these mixed valence state oxides are in-between those of the end-member $\mathrm{Ti}^{3+}$ and $\mathrm{Ti}^{4+}$ compounds. The $\mathrm{O}_{K}$ spectra, also, systematically shift to lower energy with decreasing valence state of $\mathrm{Ti}$. Energy positions in the rutile and anatase $\mathrm{O}_{K}$ energy positions reported for $\mathrm{Ti}_{3} \mathrm{O}_{5}, \mathrm{Ti}_{2} \mathrm{O}_{3}$ and $\mathrm{TiO}$ (de Groot et al. 1989)are shifted by about 0.5-0.6 eV [3].

The analyzed oxides are semi-conductors or insulators (except $\mathrm{TiO}$, which shows primarily metallic behavior) and the formed core hole is incompletely screened from the excited electron. In the case of rutile (insulator) there are no electrons on the first unoccupied $2 t_{2 g}$ level, the screening is poorest and the $L_{3,2}$ edges are shifted to higher energy losses than for metallic $\mathrm{Ti}$. In the case of the semi-conducting oxides $\left(\mathrm{Ti}_{3} \mathrm{O}_{5}, \mathrm{Ti}_{2} \mathrm{O}_{3}, \mathrm{Ti}_{4} \mathrm{O}_{7}\right.$, and $\mathrm{Ti}_{5} \mathrm{O}_{9}$ ) the $\mathrm{Ti}_{3,2}$ edges are shifted closer to the edge of metallic Ti with the $L_{3}$ edge at $456 \mathrm{eV}$ and the $L_{2}$ edge at $462 \mathrm{eV}$. TiO shows metallic conductivity almost like that in metallic $\mathrm{Ti}$. In this case the $\mathrm{Ti}_{3}$ edge is shifted to $456.6 \mathrm{eV}$. An alternative approach to explain the chemical shifts in the $T i L_{3,2}$ spectra of Ti oxides is given by Yoshiya et al. (1999) [4]. They performed first principles 
molecular orbital calculations for three $\mathrm{Ti}$ oxides ( $\mathrm{TiO}, \mathrm{Ti}_{2} \mathrm{O}_{3}, \mathrm{TiO}_{2}$ ) and suggest that the $\mathrm{Ti}-\mathrm{O}$ covalent bonding becomes stronger with decreasing number of d-electrons [4].

The gradient distribution of the vacancies through the $\mathrm{TiO}_{x}$ film from the top towards the glass substrate surface, induce appearance of the various semiconducting or metallic phases of $\mathrm{TiO}_{x}$ through the film thickness. On the top level prevailing crystal phase is anatase or rutile, emerged inside of the amorphous phase. This layer is dielectric. In the first levels below this level the $\mathrm{Ti}_{2} \mathrm{O}_{3}$ and $\mathrm{Ti}_{3} \mathrm{O}_{5}$ phases are mostly present inside of amorphous matrix as dielectric phase. Finally, closed to the substrate are levels with preferential content of metallic phase, emerged in amorphous dielectric phase. This is one rough picture of phase composition follow the change of the vacancy concentration inside of the film thickness. It seems that inside each layer is fulfilled the basic condition, that the very small particles of metallic or semiconducting phases are distributed inside of the dielectric phases, with very small energy gaps, enabling the overlapping the conduction and valence band on the surface of the active metallic phase and dielectric phase [5].

Cathodic arc evaporation (CAE) is one of the most frequently used techniques for film deposition due to the high percentage of ions in the emitted flux and their high kinetics $[6,7]$. The presence of energetic ions during the coating process is particularly desirable since it provides enhanced adhesion and increased film packing density. This technique is mainly used for the deposition of various nitrides and oxides as multilayers [8]. It is also used to obtain hard and wear-resistant coatings on different tools, decorative and protective coatings on various appliances against corrosion, electromagnetic and radiofrequency interference, etc. $[9,10]$.

CAE is especially useful for the deposition of high-quality titanium dioxide $\left(\mathrm{TiO}_{2}\right)$ films for various applications [10-12]. So obtained $\mathrm{TiO}_{2}$ films show strong mechanical and chemical stability, and good insulating properties and particularly good electrical and optical properties such as high refractive index, which makes them suitable for electro-optical devices, sensors, optical coatings and photo catalysts for oxidation of organic compounds [1215]. Doping $\mathrm{TiO}_{2}$ with nitrogen shows promising results for applications in visible-light photo catalysis [16].

In this study titanium oxide films were deposited on glass using CAE method. The films were characterized by X-ray Diffraction (XRD), Scanning Electron Microscopy (SEM), X-ray Photoelectron Spectroscopy (XPS), Fourier
Transform Infrared spectrometry (FTIR) and ellipsometry.

\section{EXPERIMENTAL SECTION}

Thin film of titanium oxides (Ti-O), was deposited on the glass substrate, by cathodic arc plasma evaporation.

The glass substrate was previously prepared by etching the $\mathrm{SiO}_{2}$ layer in an Electron Cyclotron Resonance (ECR) plasma-etching machine (PE-50 Compact Benchtop Plasma Cleaning System), The discharge was established by $2.45-\mathrm{GHz}$ circularly polarized microwaves of transverse electric waves (TE), mode, fed to the plasma chamber via a 10$\mathrm{cm}$-diameter quartz window; the 875-G ECR resonance was located at an axial position $z=42$ $\mathrm{cm}$ from the microwave entrance, near the end of the plasma chamber. Experiments were performed at an incident microwave power of $400 \mathrm{~W}$ and a $\mathrm{CF}_{4}$, gas flow rate of $10 \mathrm{~cm}^{3} / \mathrm{min}$; the reactor gas pressure was $0.02 \mathrm{~Pa}$, an acceleration electrode voltage of $500 \mathrm{~V}$, and a gap distance of $200 \mathrm{~mm}$ between the electrodes.

Ti-O films were deposited by CEA using $60 \mathrm{~A}$ target current, while oxygen was gradually introduced into the reaction chamber under controlled total gas flux $\left(\mathrm{O}_{2}+\mathrm{Ar}\right)$ at $60 \mathrm{sccm}$ (standard cubic centimeters per minute), and ratio $\mathrm{O}_{2} / \mathrm{Ar}$ 3:1 (flux of the process gas $\mathrm{O}_{2}$ was $50 \mathrm{sccm}$ ). The substrate was placed on a turntable holder heated up to $200{ }^{\circ} \mathrm{C}$ and the pulsed bias voltage was kept at $-50 \mathrm{~V}$ during the deposition.

For a CEA a pure titanium $(99.99 \%)$ cathode, running at $100 \mathrm{~A}$ was used to generate Ti ions. The vacuum chamber, with a base pressure in the range of $10^{-4} \mathrm{~Pa}$, was backfilled with oxygen at a flow of $50 \mathrm{sccm}$, resulting in a working pressure of $0.36 \mathrm{~Pa}$, which decreased during the process to 0.2 $\mathrm{Pa}$. The samples were mounted at a distance of 39 $\mathrm{cm}$ to the cathode for a treatment time of 5 minutes. The samples were normally at ground potential, exposed to the negative high voltage pulses between 1 and $10 \mathrm{kV}$ with a length of $30 \mu \mathrm{s}$ and a repetition rate of $3 \mathrm{kHz}$. Over the treatment time of 5 min from the arc ignition, constant oxygen flow in the range of $30 \mathrm{sccm}$ up to $100 \mathrm{sccm}$ was held in the chamber. The working pressure was in the range of $0.03 \mathrm{~Pa}$ up to $0.3 \mathrm{~Pa}$. After the arc ignition, the pressure decreased because of the high reactivity of the titanium layer deposition. The turntable sample holder, from aluminum with a diameter of $7.5 \mathrm{~cm}$ of diameter, is positioned at a distance of $39 \mathrm{~cm}$ from the cathode (pure titanium (99.99\%) cathode) into a cylindrical vacuum chamber with $700 \mathrm{~mm}$ diameter and a height of $650 \mathrm{~mm}$.

Phase composition of the samples was analyzed by XRD (Philips PW 1051 Powder 
Diffractometer using Ni-filtered $\mathrm{Cu} \mathrm{Ka}$ radiation) and FTIR (Nicolet IS 50 FT-IR Spectrometer) methods. Microstructure of the samples was analyzed by SEM (JEOL 5300).

XPS depth profiling was carried out on a SPECS customized UHV surface analysis system containing sputter ion gun, PHOIBOS 100 spectrometer for energy analysis, dual anode $\mathrm{Al} / \mathrm{Ag}$ monochromatic source and electron flood gun. XPS spectra were taken using monochromatic Al Ká line (photon energy of $1486.74 \mathrm{eV}$ ) in FAT 20 mode with energy step of $0.1 \mathrm{eV}$ and dwell time of 1-2 $s$ depending on the considered line. The main lines of oxygen, titanium, carbon, nitrogen and copper (including its Auger line) were followed

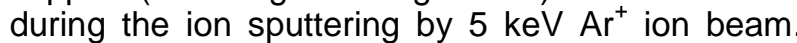
The incident angle was $40^{\circ}$ with respect to the sample surface. The sputtered area was about $5 \times 5$ $\mathrm{mm}^{2}$, and the typical primary beam current was about $1.8 \mu \mathrm{A}$.

All contributions of photoelectron lines were fitted to symmetric pseudo-Voigt profiles represented by a product of a Gaussian $(70 \%$ of the total intensity) and Lorentzian (30\% of the total intensity) lines. The intensity ratio $\mathrm{Ti} 2 \mathrm{p}_{3 / 2}: \mathrm{Ti} 2 \mathrm{p}_{1 / 2}$ of each bond was fixed to the theoretical $2: 1$. The position of a $\mathrm{Ti} 2 \mathrm{p}$ contribution with the highest binding energy, attributed to the $\mathrm{TiO}_{2}$ phase, was used as a binding energy reference (458.6 eV) unless otherwise stated. It should be also stressed that positions from the literature of other phases (e.g. $\mathrm{Ti}_{2} \mathrm{O}_{3}$ or $\mathrm{TiO}$ ) are much less reliable $[2,3]$ since they rather represent various defects than well defined chemical phases.
Ellipsometric analysis was performed using a J.A. Woollam variable angle spectroscopic ellipsometer (Model VB-400) and the estimation of optical parameters was performed by the ellipsometric analysis program WVASE32. The ellipsometric analysis was performed to $300-2500$ $\mathrm{nm}$ and $50,60,70$ degrees. The fitting procedure is made to WASE software (J.A. Woollam Co, Lincoln, NE 68508, USA), and to calculate the optical parameters and thickness, using minimized the mean square error (MSE) given by:

$$
M S E=\sqrt{\frac{1}{2 N-M} \sum_{i=1}^{N}\left[\left(\frac{\psi_{i}^{\bmod }-\psi_{i}^{\exp }}{\sigma_{\psi, i}^{\exp }}\right)^{2}+\left(\frac{\Delta_{i}^{\bmod }-\Delta_{i}^{\exp }}{\sigma_{\Delta, i}^{\exp }}\right)^{2}\right]}
$$

where $\mathrm{N}$ is the number of amplitude incident waves $\Psi$ and phase difference $\Delta$, e.g. $(\Psi, \Delta)$ pairs, $M$ is the number of variable parameters in the model, and $\sigma$ is the standard deviations on the experimental data points.

\section{RESULTS AND DISCUSSION}

\section{1. $X R D$ analysis}

Representative diffractograms of the three films are presented in Figure 1.The XRD pattern of the $\mathrm{Ti}-\mathrm{O}$ film shows the presence of titanium oxides: $\mathrm{Ti}_{2} \mathrm{O}_{3}$ (planes (012), (104), (110), (116), (300) and $(1010)$ at $23.33,32.71,35.21,53.47,62.48$ and $71.10^{\circ}$, respectively, JCPDS card no. 89-4746) [17] and $\mathrm{TiO}$ (planes (020), (002) and (4-20) at 19.53, 43.42 and $\left.63.14^{\circ}, \mathrm{JCPDS} 08-0117\right)$, respectively [18]. It should be emphasized that the $\mathrm{TiO}_{2}$ phase was not observed.

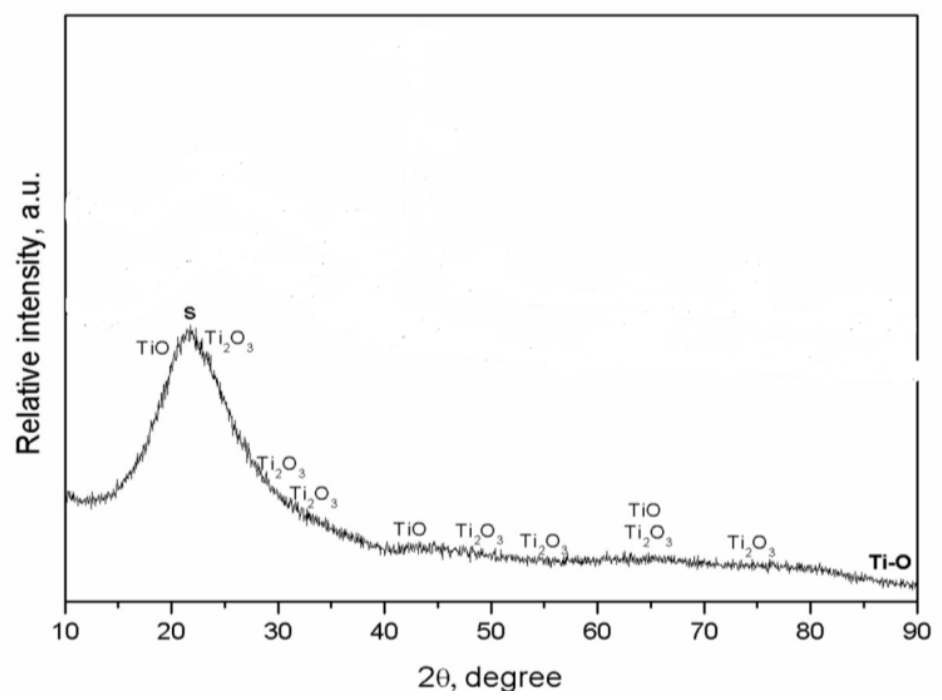

Figure 1. XRD diffractograms of Ti-O thin films. Positions of the expected main features are labeled in the diffractograms

Slika 1. XRD difraktogrami Ti-O tankog filma. Položaji glavnih maksimuma su naznačeni na difraktogramima 


\subsection{FTIR analysis}

FTIR spectra of all samples are shown in Figure 2. The bands between 1868 and $2076 \mathrm{~cm}^{-1}$ indicate the formation of some new species in $\mathrm{Ti}-\mathrm{O}$ during oxygen and/or nitrogen doping. The bands between 1649 and $1653 \mathrm{~cm}^{-1}$ correspond to bending vibrations of $\mathrm{O}-\mathrm{H}$, while the bends between 1371 and $1557 \mathrm{~cm}^{-1}$ can be assigned to vibration of the $\mathrm{CO}^{2-}$ inside of the carbonate impurities. The bands at $418-1004 \mathrm{~cm}^{-1}$, including strongly expressed broadband at $850 \mathrm{~cm}^{-1}$, can be assigned to $\mathrm{Ti}-\mathrm{O}-\mathrm{Ti}$ stretching vibration and vibration on the level of Ti-O bond, showing some cleavage into Ti-O-Ti bonds $[19,20]$.

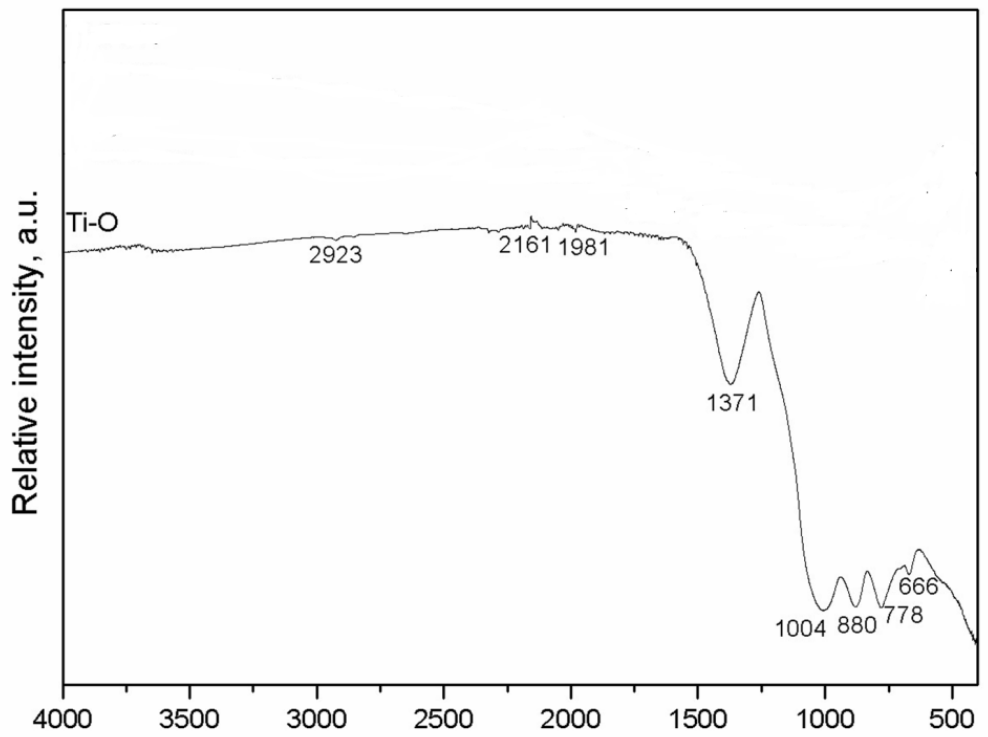

Figure 2. FTIR spectra of the surface of Ti-O thin film

Slika 2. FTIR spektri površine Ti-O tankog filma

\subsection{SEM analysis}

SEM micrographs (Figure 3) show slight structure irregularities on the surface of $\mathrm{Ti}-\mathrm{O}$ films. This proves that during the deposition, film layers were almost epitaxially ordered one above another.

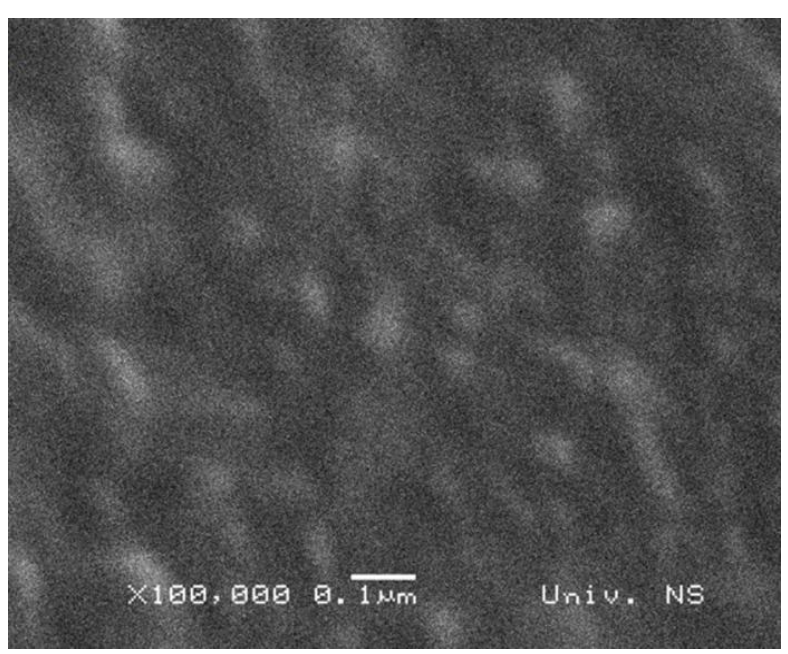

Figure3. SEM micrographs of the deposited Ti-O films

Slika 3. SEM mikrofotografije deponovanih Ti-O filmova
Observed irregularities of the films are probably induced by the structure irregularities on the substrate surface and stocking fault of neighbor layers during deposition influenced by the presence of these hills.

\subsection{XPS analysis}

\subsubsection{General remarks}

Various types of titanium oxides have been thoroughly studied by means of XPS. Particularly useful conclusions can be drawn from the analyses of rutile and anatase $\mathrm{TiO}_{2}$ single crystals, since these surfaces can be prepared in a reproducible way, thus maintaining high purity and low concentration of defects. Such samples have deficiency in oxygen, which is manifested as oxygen vacancies at the sample surface and $\mathrm{Ti}^{3+}$ interstitials in bulk of the $\mathrm{TiO}_{2}$ crystalline structure [21]. Nevertheless, XPS composition analyses of such samples apparently reveal access to oxygen. Most probably, a reason for apparent deficiency of $\mathrm{Ti}$ is the same as in the Ti-O-N system, which was studied in detail by Jeager and Patscheider [22]. They showed that the problem is in inadequate background subtraction of photoelectron lines. Commonly applied Shirley background underestimates $\mathrm{Ti} 2 \mathrm{p}$ line intensity. Although the problem can be solved by using more reliable 
Tougaard background, this is rarely done since the spectrum has to be taken in a rather large energy range (of the order of $100 \mathrm{eV}$ ) for its proper evaluation. Therefore, more practical procedure for obtaining the oxygen content would be by fitting the $\mathrm{Ti} 2 \mathrm{p}$ line. In general, this photoelectron line will have three contributions, attributed to $\mathrm{Ti}(\mathrm{IV}), \mathrm{Ti}(\mathrm{III})$ and $\mathrm{Ti}(\mathrm{II})$ oxidation states (i.e. $\mathrm{TiO}_{2}, \mathrm{Ti}_{2} \mathrm{O}_{3}$ and $\mathrm{TiO}$ in the case of titanium oxide samples). Their $\mathrm{Ti}$ $2 \mathrm{p}_{3 / 2}$ lines are situated at $458.6 \mathrm{eV}, 457.2 \mathrm{eV}$ and $455.2 \mathrm{eV}$, respectively [23]. Then, $\mathrm{O}: \mathrm{Ti}$ ratio $\left(\mathrm{C}_{\mathrm{O}}: \mathrm{C}_{\mathrm{T}_{\mathrm{i}}}\right)$ can be evaluated from the relative intensities of the three contributions. If $\mathrm{C}_{\mathrm{TiO}}, \mathrm{C}_{\mathrm{Ti} 2 \mathrm{O} 3}$ and $\mathrm{C}_{\mathrm{TiO} 2}$ are relative intensities of the corresponding contributions $\left(\mathrm{C}_{\mathrm{TiO}}+\mathrm{C}_{\mathrm{Ti} 2 \mathrm{O} 3}+\mathrm{C}_{\mathrm{TiO} 2}=\right.$ 1), the ratio can be calculated as $\mathrm{C}_{\mathrm{O}}: \mathrm{C}_{\mathrm{Ti}}=\mathrm{C}_{\mathrm{TiO}} \cdot 2+$ $\mathrm{C}_{\mathrm{Ti} 203} \cdot 1.5+\mathrm{C}_{\mathrm{TiO}}$. $\mathrm{TiO}$ phase can also differ from the other $\mathrm{Ti}$ oxides from the $\mathrm{O}$ 1s line analysis (the contribution at about $531.2 \mathrm{eV}$ [24]), which is not the case with $\mathrm{Ti}(\mathrm{III})$ and $\mathrm{Ti}(\mathrm{IV})$ oxidation states (they have common contribution at about 529.7 [23] i.e. $530.1 \mathrm{eV}$ [24]). In addition, one can use $\mathrm{O}$ 1s photoelectron line to identify hydroxylated surfaces (e.g. adsorbed $\mathrm{OH}$ groups) and oxygen in organic species, being typical organic contaminants.

\subsubsection{Modeling surface alteration by ion bombardment}

Measuring the depth distribution of titanium oxide phases by means of XPS sputter depth profiling affects surface composition due to the preferential sputtering of oxygen. Ion bombardment of $\mathrm{TiO}_{2}$ crystal will alter its surface composition by introducing oxygen vacancies, which is manifested as appearance of $\mathrm{Ti}(\mathrm{III})$ and $\mathrm{Ti}(\mathrm{II})$ contributions and simultaneous decrease of the $\mathrm{Ti}(\mathrm{IV})$ contribution. Loss of surface oxygen commonly takes place during the sputter cleaning of $\mathrm{TiO}_{2}$ single crystals in surface science experiments [25]. The crystals are then annealed typically to $600-700{ }^{\circ} \mathrm{C}$, which promotes surface segregation of oxygen from the bulk. The annealing results in establishing thermodynamically stable $\mathrm{TiO}_{2}$ surface with a low number of defects, and $\mathrm{TiO}_{2}$ crystalline structure in the bulk with $\mathrm{Ti}^{3+}$ ions occupying the interstitial sites. The latter is the reason why so-called reduced (i.e. oxygen deficient) $\mathrm{TiO}_{2}$ crystals behave as $\mathrm{N}$-type semiconductors, which is manifested as the change of their color [21]. The amount of surface defects can be additionally reduced if the annealing is performed in oxygen atmosphere [26].

Preferential sputtering of oxygen will be taking place for any titanium oxide sample, and potentially alter the depth distribution of oxide phases. The dynamics of this change were studied by Hashimoto and Tanaka [27], who were performing XPS analysis of $\mathrm{TiO}_{2}$ surface during the depth profiling. In the case of sputtering by $2 \mathrm{keV} \mathrm{Ar}^{+}$ ions impinging at $\alpha=36^{\circ}$ with respect to the sample surface, $\mathrm{Ti}(\mathrm{IV})$ contribution was reduced to $14.3 \%$ in the equilibrium, while $\mathrm{Ti}(\mathrm{III})$ and $\mathrm{Ti}(\mathrm{II})$ contributions both equaled about $42.3 \%$ of the total Ti $2 p$ line intensity. The equilibrium ratio $C_{0}: C_{T}$, estimated from the relative contributions of the $\mathrm{Ti}$ $2 p$ line, is about 1.35. The latter was achieved at ion fluence of about $5.6 \times 10^{15}$ ions $/ \mathrm{cm}^{2}$.

W performed dynamic Monte Carlo simulations of $\mathrm{TiO}_{2}$ sputtering by $\mathrm{Ar}^{+}$ions using $\mathrm{FZR}$ version of the TRIDYN 4.0 code [28], developed in the Forschungszentrum, Rossendorf, Germany [29]. The most critical parameters in ion sputtering calculations are surface binding energies, SBE. In our simulations we used variable surface binding energies, which depend on the surface composition:

$$
S B E_{T i(O)}=U_{T i(O)-T i(O)} \cdot x_{T i(O)}+U_{O-T i} \cdot x_{O(T i)} \text {. }
$$

$U_{A-B}$ is the surface binding energy contribution due to the $A-B$ bonding, while $x_{A}$ is relative surface concentration of element ' $A$ '. The parameters $U$ were chosen according to the recommendations [29] $\mathrm{U}_{\mathrm{Ti}-\mathrm{Ti}}=4.89 \mathrm{eV}$ (sublimation energy of $\mathrm{Ti}$ metal), $\mathrm{U}_{\mathrm{O}-\mathrm{O}}=0.0 \mathrm{eV}\left(\mathrm{O}_{2}\right.$ is gas), while $\mathrm{U}_{\mathrm{Ti}-\mathrm{O}}$ was calculated from the formation enthalpy of the particular oxide phase and the dissociative energy of the $\mathrm{O}_{2}$ molecule. The simulations were performed with 100000 ion trajectories, for the total fluence of $2 \times 10^{16} \mathrm{~cm}^{2}$. The results of the TRIDYN simulations, together with the input parameters and used values for $\mathrm{U}_{\mathrm{Ti}-\mathrm{O}}$, are summarized in Table 1 .

Table 1. Result of the Monte Carlo simulation of $\mathrm{Ar}^{+}$sputtering of titanium oxides

Tabela 1. Rezultat Monte Karlo simulacije $\mathrm{Ar}^{+}$spaterovanja titanovih oksida

\begin{tabular}{|c|c|c|c|c|c|c|}
\hline sample & $\mathrm{E}(\mathrm{eV})$ & $\alpha\left(^{\circ}\right)$ & $\mathrm{U}_{\mathrm{Ti}-\mathrm{O}}(\mathrm{eV})$ & $\Phi_{\text {eq }}\left(\mathrm{ions} / \mathrm{cm}^{2}\right)$ & $\mathrm{Y}_{\text {eq }}$ (atoms/ion) & $\left(\mathrm{C}_{\mathrm{O}}: \mathrm{C}_{\mathrm{Ti}}\right)_{\mathrm{eq}}$ \\
\hline $\mathrm{TiO}_{2}$ & 2000 & 36 & 13.66 & $6 \times 10^{15}$ & 2.8 & 1.30 \\
\hline $\mathrm{TiO}_{2}$ & 5000 & 0 & 13.66 & $1.9 \times 10^{16}$ & 1.17 & 1.27 \\
\hline $\mathrm{TiO}_{2}$ & 5000 & 40 & 13.66 & $1.2 \times 10^{16}$ & 3.2 & 1.27 \\
\hline $\mathrm{Ti}_{2} \mathrm{O}_{3}$ & 5000 & 40 & 12.2 & $1.7 \times 10^{16}$ & 3.4 & 1.01 \\
\hline $\mathrm{TiO}$ & 5000 & 40 & 10.4 & $1.6 \times 10^{16}$ & 3.6 & 0.75 \\
\hline
\end{tabular}


Simulation of $\mathrm{TiO}_{2}$ sputtering by $\mathrm{Ar}^{+}$with the input parameters corresponding to the experiment [27] 'showed that the equilibrium approximation is obtained after $6 \times 10^{15}$ ions $/ \mathrm{cm}^{2}$ with the O:Ti ratio of 1.30 , i.e. very close to the experimental result. The second test of the $\mathrm{TiO}_{2}$ sputtering simulation was to evaluate equilibrium sputtering yield for $5 \mathrm{keV} \mathrm{Ar}^{+}$ ions at normal incidence. The simulation result is 1.1 atoms/ion, which, considering both experimental and simulation uncertainties, agrees very well with the experimental result of 0.9 atoms/ion [30]. The latter case was also treated using the analytical model of Seah and Nunney [31] for evaluating ion sputtering yield of twocomponent compounds at normal incidence. For the same surface binding energies, we obtained for the total sputtering yield 1.17 atoms/ion, which is quite close to the simulation result. In addition, the equilibrium surface concentration ratio $\mathrm{O}: \mathrm{Ti}$ obtained by both simulation and the analytical model is 1.27. All these results strongly support the choice of the overall approach for modeling surface modification of titanium oxides by ion sputtering.

Simulation of $\mathrm{TiO}_{2}$ ion sputtering for the input parameters that correspond to our experiment ( 5 $\mathrm{keV} \mathrm{Ar}^{+}$ions impinging the surface at $40^{\circ}$ ) using the same approach showed that the equilibrium surface stoichiometry O:Ti equal to 1.27 is reached for the ion fluence of $1.2 \times 10^{16}$ ions $/ \mathrm{cm}^{2}$. In the case of $\mathrm{Ti}_{2} \mathrm{O}_{3}$ sputtering under the same conditions, the simulation predicts that equilibrium surface stoichiometry $\mathrm{O}: \mathrm{Ti}$ of 1.01 should be obtained at the ion fluence of $1.7 \times 10^{16}$ ions $/ \mathrm{cm}^{2}$. In the case of $\mathrm{TiO}$, equilibrium surface stoichiometry $\mathrm{C}_{\mathrm{O}}: \mathrm{C}_{\mathrm{Ti}}=$ 0.75 is achieved at the ion fluence of $1.6 \times 10^{16}$ ions $/ \mathrm{cm}^{2}$. These results are the estimations of the oxygen surface deficiency just due to the ion bombardment.

\subsubsection{XPS analysis of Ti-O sample}

XPS analyses of as-received Ti-O samples reveal presence of a single contribution with $\mathrm{Ti}$ $2 p_{3 / 2}$ line at $458.5 \mathrm{eV}$, which can be readily attributed to $\mathrm{TiO}_{2}$. This is further supported by the $\mathrm{O}$ 1s line position at about $530.0 \mathrm{eV}[23,24]$. Although ion sputtering reduces $\mathrm{C}_{0}: \mathrm{C}_{\mathrm{Ti}}$ ratio, its decrease is much smaller than it is predicted by the Monte Carlo simulations. High-resolution spectrum of the $\mathrm{Ti} 2 \mathrm{p}$ line taken from the Ti-O sample after the ion bombardment with the total fluence of about $3 \times 10^{16}$ ions $/ \mathrm{cm}^{2}$ is presented in Figure $4 . \mathrm{TiO}_{2}$ phase is still dominant phase at the surface $\left(\mathrm{C}_{\mathrm{TiO} 2}=\right.$ $84.1 \%)$, accompanied with $\mathrm{Ti}(\mathrm{III})$ contribution $\left(\mathrm{C}_{\mathrm{Ti} 2 \mathrm{O}}\right.$ $=15.9 \%$ ), whilst TiO was not detected. At the same time, hydrocarbon surface contamination was efficiently removed by ion bombardment, proving that the measured area was indeed sputtered.

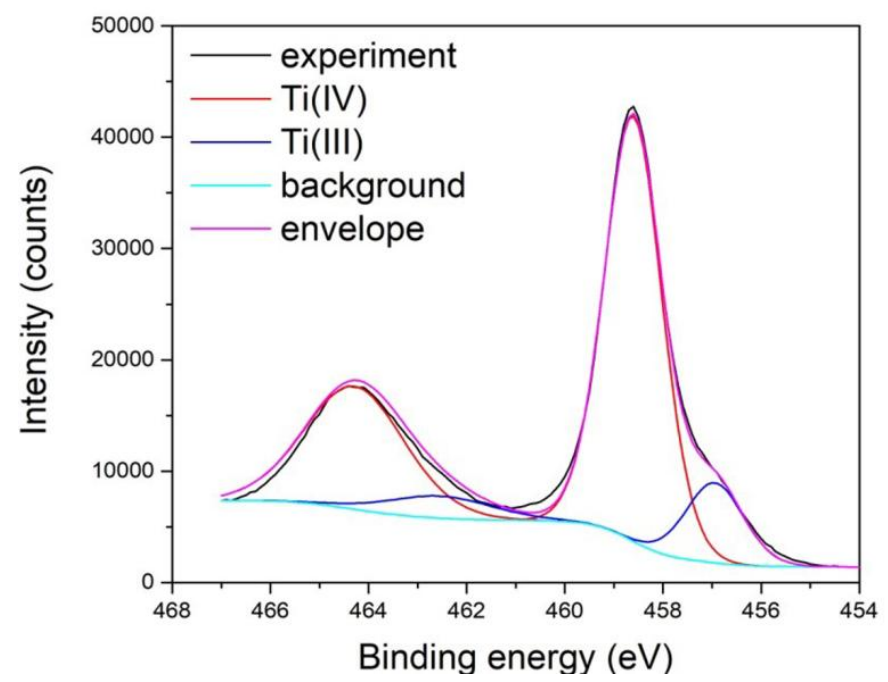

Figure 4. High resolution XPS spectrum of Ti $2 p$ photoelectron line taken from sputter cleaned Ti-O sample, and the corresponding fitting

Slika 4. Visoko rezolucioni XPS spektar Ti 2p fotoelektronske linije uzorka Ti-O, koji je prethodno očišćen spaterovanjem i odgovarajuće fitovanje

Valence band of the Ti-O sample is presented in Figure 5. The width of this structure is not governed by the instrumental function of the XPS system [32], but by non-uniform charging of the sample that introduces broadening of all lines. The asymmetric shape of the valence band resembles that of anatase, and its maximum is situated at about $2.6 \mathrm{eV}$ according to the results from the literature [33]. In addition, a small hump at the position of the Fermi level (which is not physical) can only correspond to $\mathrm{Ti} 3 \mathrm{~d}$ states i.e. it is evidence of the $\mathrm{Ti}(\mathrm{III})$ oxidation state. Shift of its 
position towards lower binding energies for about 1 eV [34] could mean differential charging between $\mathrm{Ti}(\mathrm{IV})$ and $\mathrm{Ti}(\mathrm{III})$ islands. This explanation apparently contradicts position of the $\mathrm{Ti}$ (III) contribution in the $\mathrm{Ti} 2 \mathrm{p}_{3 / 2}$ photoelectron line at $456.95 \mathrm{eV}$, agreeing very well with the literature findings [23]. However, one should also consider different information depths of photoelectrons with binding energy at about $460 \mathrm{eV}$ and $0 \mathrm{eV}$ due to the different inelastic mean free paths. Valence band photoelectrons originate, on average, from deeper layers as compared to $\mathrm{Ti} 2 p$ photoelectrons. Therefore, electric potential difference between the thin film surface and interior could explain this additional energy shift of $1 \mathrm{eV}$.

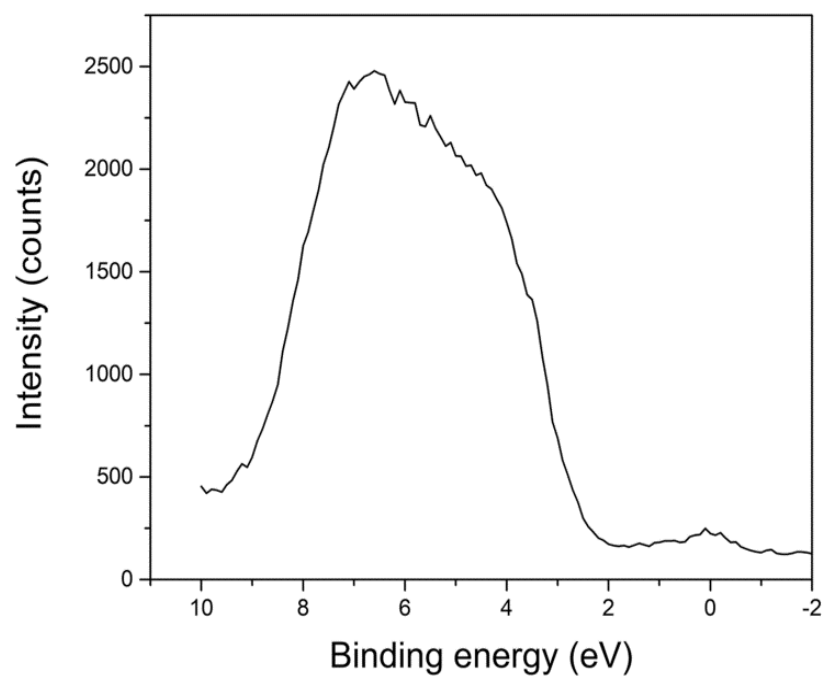

Figure 5. Valence band of the sputter cleaned Ti-O sample taken on the XPS instrument

\section{Slika 5. Valentna traka prethodno očišćenog spaterovanjem Ti-O uzorka dobijena pomoću XPS spektrometra}

Slight reduction of the $\mathrm{TiO}_{2}$ surface phase with intense ion bombardment, totally opposite from $\mathrm{TiO}_{2}$ single crystal, is most probably due to the specific thin film structure. While only annealing above $600{ }^{\circ} \mathrm{C}$ sufficiently increases oxygen mobility in rutile single crystal to enable its surface segregation, very fast migration of oxygen atoms takes place in Ti-O sample during the sputtering. The latter compensates to a large extent the oxygen removal due to the preferential sputtering. Therefore, sputter depth profiling is not able to provide information on the thin film interior. Broad peaks attributed to different titanium oxide phases (excluding $\mathrm{TiO}_{2}$ ) in X-ray diffractograms (cf. Fig. 1) imply nanocrystalline structure of the thin films. Efficient migration of oxygen atoms could be achieved via different kind of defects, including grain boundaries.

Both XRD and FTIR show that Ti-O sample consists mainly of $\mathrm{Ti}_{2} \mathrm{O}_{3}$ phase, accompanied by $\mathrm{TiO}$ in the $\mathrm{Ti}-\mathrm{O}$ sample. This result apparently contradicts the XPS findings, which reveal $\mathrm{TiO}_{2}$ phase at the surface closest to anatase. However, one should have in mind that anatase and rutile are the most stable oxide phases of titanium [33]. Therefore, surface segregation of oxygen is triggered by minimization of the free Gibbs energy.
Slight reduction of the $\mathrm{TiO}_{2}$ surface phase with intense ion bombardment, totally opposite from $\mathrm{TiO}_{2}$ single crystal, is most probably due to the specific thin film structure. While only annealing above $600{ }^{\circ} \mathrm{C}$ sufficiently increases oxygen mobility in e.g. rutile single crystal to enable its surface segregation, very fast migration of oxygen atoms takes place in Ti-O sample during the sputtering at room temperature. The latter compensates to a large extent the oxygen removal due to the preferential sputtering. Hence, sputter depth profiling is not able to provide direct insight into the thin film interior. Broad peaks attributed to different titanium oxide phases (excluding $\mathrm{TiO}_{2}$ ) in X-ray diffractograms (cf. Figure 1a) imply nanocrystalline structure of all thin films. Efficient migration of oxygen atoms could be achieved via different kinds of defects, including grain boundaries.

\subsection{Spectroscopic ellipsometry}

Ellipsometry is a technique that uses polarized light and the relative phase change in a beam of reflected polarized light. It's a very sensitive measurement and more accurate that intensity reflectance. Research data for all samples are available at repository [34]. 


\subsubsection{Ellipsometric spectra of Ti-O sample}

Ellipsometric spectra of $\mathrm{TiO}_{2-x}$ layer was simulated with EMA layer, with a Ti layer $(3.2 \%)$ and $\mathrm{a} \mathrm{TiO}_{2-x}$ layer $(96.8 \%)$, on the glass substrate as reported in Scheme 1. To describe the optical properties of $\mathrm{TiO}_{2-x}$ a Tauc-Lorentz oscillator [35] was used while for description of $\mathrm{Ti}$ layer were used: Gaussian Oscillator [36], Drude oscillator [37] and Lorentz oscillator [38]. The optical properties of $\mathrm{TiO}_{2-\mathrm{x}}$ top layer $(96.8 \%)$ were illustrated in Figure $6 \mathrm{~b}$. The maximum value of the refractive index is 3.35 at $330 \mathrm{~nm}$ while the lowest value is 2.25 at $2500 \mathrm{~nm}$, showing parabolic decrease between its maximal and minimal value.

This decrease of refractive index may be influenced by destructive interference between plasmonic wave induced by electron oscillations in semi-conductive phases $\left(\mathrm{Ti}_{2} \mathrm{O}_{3}\right.$ and $\left.\mathrm{Ti}_{4} \mathrm{O}_{7}\right)$ on the boundary surface with dielectric phases (anatase, rutile and amorphous $\mathrm{TiO}_{2}$ ) and incident wave of light [30-41]. In addition, the extinction coefficient shows sharp drop from its maximal value of about 1.05 at $310 \mathrm{~nm}$, reaching zero value at $380 \mathrm{~nm}$. The extremely low extinction coefficient with value zero in all areas wavelengths from 380 shows the potentially high efficiency of transformation of light energy into heat energy which can be interesting for applications as heat capacitors.

\begin{tabular}{|l|c|}
\hline SRough & $5.93 \mathrm{~nm}$ \\
\hline $\mathrm{TiO}_{2}$ - EMA layer Ti(3.2\%) - TiO2(96.8\%) & $244.94 \mathrm{~nm}$ \\
\hline Ti bottom layer & $25,6 \mathrm{~nm}$ \\
\hline Glass Substrate & $1 \mathrm{~mm}$ \\
\hline
\end{tabular}

Scheme 1. Model used for extract the optical parameters for TiO2-x and Ti layers

Shema 1. Model koji je korišćen za ekstrakciju optičkih parametara za Ti-O i Ti slojeve

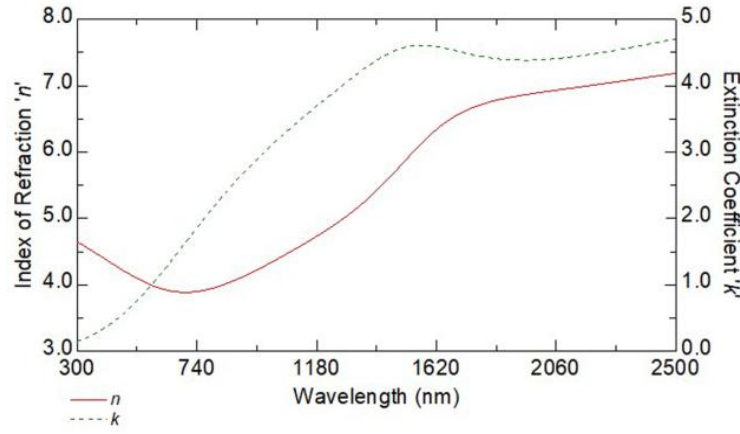

a)

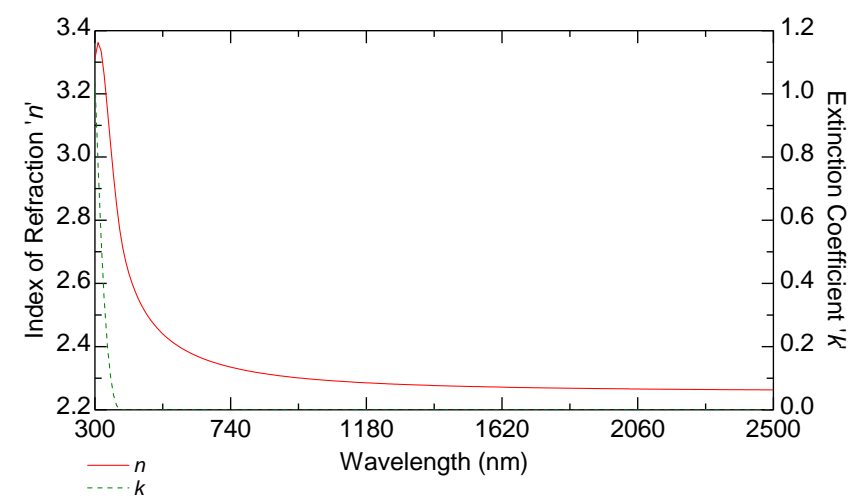

b)

Figure 6. Dependence of refractive indices and extinction coefficients of Ti-sub-layer and $\mathrm{TiO}_{2-x}$ top layer on wavelength incident waves

Slika 6. Zavisnost indeksa prelamanja I koeficijenta ekstinkcije Ti-podsloja i $\mathrm{TiO}_{2-x}$ vršnog sloja od talasne dužine incidentnih talasa

The optical properties of $\mathrm{Ti}$ sub-layer are illustrated in Figure 6a. Ti layer, show very high values of the refractory indices between 1300 and $2500 \mathrm{~nm}$. This sub-layer exhibits pronounced plasmonic properties, typical for materials with significantly increased refractory index. In this layer probably constructive interference of plasmonic waves is occurred.

The largest changes in refractive index are near the band-gap. It is positive for energies below the band gap, a result of the increase in absorption coefficient for fixed energies. The band filling and band-gap shrinkage effects are very important for inter-band transitions, because the absorption of the photon of incident wave is enough to move the electron within a conductive band. In the Drude model, the intra-band free-carrier absorption, known as the plasma effect, is directly proportional to the concentration of electrons and holes and the square of the wavelength. On the other hand, both the band filling and band-gap shrinkage effects on refractive index are largest near the band-gap, inducing in the case of Ti-sublayer ultrahigh refractive indices, induces by the constructive interference of the plasmonic and light electromagnetic waves [41].

\section{CONCLUSIONS}

On the basis of analyses, the deep insight in the changes of the phase composition from the top level of the thin films to the substrate is given in detail. For the Ti-O samples oxidative state of $\mathrm{Ti}$ decreases from $\mathrm{Ti}(\mathrm{IV})$ oxidation state at the surface to $\mathrm{Ti}(\mathrm{II})$ in deeper layers of the film. 
XPS analysis shows a very fast migration of oxygen atoms in Ti-O sample during the sputtering.

The extinction coefficient of Ti-O sample shows zero value at $370 \mathrm{~nm}$, typical for exceptionally good capacitors.

\section{Acknowledgment}

This study was supported by the Ministry of Education, Science and Technological Development of the Republic of Serbia (Projects No. 172026 and III45005), as well as by the Portuguese National Funding Agency for Science, Research and Technology in the framework of the project UID/FIS/00068/2019.

\section{Data availability}

The raw data required to reproduce these findings are available to download from [https:// data.mendeley.com/datasets/9vxkwwmmgc/1]. The processed data required to reproduce these findings are available to download from [https://data. mendeley.com/datasets/9vxkwwmmgc/1].

\section{REFERENCES}

[1] R.D.Leapman, L.A.Grunes, P.L.Fejes (1982) Study of the L23 edges in the $3 d$ transition metals and their oxides by electron-energy-loss spectroscopy with comparisons to theory, Phys. Rev., B 26, 614620.

[2] R.Brydson, H.Sauer, W.Engel, J.M.Thomass, E. Zeitler, N.Kosugi, H.Kuroda (1989) Electron energy loss and X-ray absorption spectroscopy of rutile and anatase: a test of structural sensitivity, J. Phys.: Cond. Matter, 1(4), 131-139.

[3] F.M.F. de Groot, M.Grioni, J.C.Fuggle, J.Ghijsen, G.A.Sawatzky, H.Peters (1989) Oxygen 1s x-rayabsorption edges of transition-metal oxides, Phys. Rev., 40, 5715-5723.

[4] M.Yoshiya, I.Tanaka, K.Kaneko, H.Adachi (1999) First principles calculation of chemical shifts in ELNES/NEXAFS of titanium oxides, J.Phys.: Cond. Matter, 11(16), 3217-3225.

[5] A.Sarkar, G.G.Khan (2019) The formation and detection techniques of oxygen vacancies in titanium oxide-based nanostructures, Nanoscale, 11(8), 3414-3444.

[6] P.J.Martin, D.R.McKenzie, R.P.Netterfield, P.Swift, S.W.Filipczuk, K.H.Müller, C.G.Pacey, B.James (1987) Characteristics of titanium arc evaporation processes, Thin Solid Films, 153, 91-102.

[7] A.Bendavid, P.J.Martin (2014) Review of thin film materials deposition by the filtered cathodic vacuum arc process at CSIRO, J.Aust.Ceram. Soc., 50, 86-101.

[8] J.Q.Zhu, M.P.Johansson-Jöesaar, P.Polcik, J. Jensen, G.Greczynski, L.Hultman, M.Odén (2013) Influence of Ti-Si cathode grain size on the cathodic arc process and resulting Ti-Si-N coatings, Surf. Coatings Technol., 235, 637-647.

[9] I.Razvan, V.I.Antoniac, M.C.Cotrut, F.Miculescu, V. Eugeniu, C.Munteanu, D.Moldan, M.Niculescu (2014) Potential Solutions to Increase the
Corrosion Resistance of Metallic Surgical Instruments Using Different Types of Ceramic Coatings, Key Eng. Mater., 614, 206-211.

[10] A.A.Vereschaka, S.N.Grigoriev, A.S.Vereschaka, A.Y.Popov, A.D.Batako (2014) Nano-scale multilayered composite coatings for cutting tools operating under heavy cutting conditions, in Procedia CIRP, Elsevier, p. 239-244.

[11] M.Lilja, J.Forsgren, K.Welch, M.Åstrand, H. Engqvist, M.Strømme (2012) Photocatalytic and antimicrobial properties of surgical implant coatings of titanium dioxide deposited though cathodic arc evaporation, Biotechnol. Lett., 34, 2299-2305.

[12] Z.Zhao, B.K.Tay, G.Yu (2004) Room-temperature deposition of amorphous titanium dioxide thin film with high refractive index by a filtered cathodic vacuum arc technique, Appl. Opt., 43, 1281-1292.

[13] R.Wang, K.Hashimoto, A.Fujishima, M.Chikuni, E. Kojima, A.Kitamura, M.Shimohigoshi, T. Watanabe (1997) Light-induced amphiphilic surfaces, Nature, $388,431-432$.

[14] O.Carp, C.L.Huisman, A.Reller (2004) Photoinduced reactivity of titanium dioxide Prog. Solid State Chem., 32, 33-177.

[15] P.Patsalas, N.Kalfagiannis, S.Kassavetis (2015) Optical Properties and Plasmonic Performance of Titanium Nitride,Materials, 8(6), 3128-3154.

[16] T.Lindgren, J.M.Mwabora, E.Avandaño, J. Jonsson, A.Hoel, C.G.Granqvist, S.E.Lindquist (2003) Photoelectrochemical and Optical Properties of Nitrogen Doped Titanium Dioxide Films Prepared by Reactive DC Magnetron Sputtering, J.Phys.Chem.B, 107, 5709-5716.

[17] M.M.An.Sinthiya, N.Kumaresan, K.Ramamurthi, K. Sethuraman (2019) Development of pure rutile TiO2TiO2 and Magneli titanium sub-oxide microstructures over titanium oxide-seeded glass substrates using surfactant-free hydrothermal process, Bull. Mater. Sci., 42(20), 127-136.

[18] J.Fukushima, H.Takizawa (2018) Size Control of Ti4O7 Nanoparticles by Carbothermal Reduction Using a Multimode Microwave Furnace, Crystals, 8, 444-452.

[19] V.Jokanović, B.Ĉolović, B.Jokanović, S. Stojadinović, A.P.Trajkovska, I.Nasov (2016) Plasmonic metamaterials based on titanium oxides, Mater. Prot. (in Serbian), 57, 225-231.

[20] V.R.Jokanović, B.Colovic, M.Nenadović, A. Trajkovska Petkoska, M.Mitrić, B.Jokanovic, I. Nasov (2016) Ultra-High and Near-Zero Refractive Indices of Magnetron Sputtered Thin-Film Metamaterials Based on TixOy, Adv. Mater. Sci. Eng., 33, 9-16.

[21] U.Diebold (2003) The surface science of titanium dioxide, Surf. Sci. Rep., 48, 53-229.

[22] D.Jaeger, J.Patscheider (2012) A complete and self-consistent evaluation of XPS spectra of TiN, J. Electron Spectros. Relat. Phenomena, 185, 523534.

[23] M.C.Biesinger, L.W.Lau, A.R.Gerson, R.C.Smart (2010) Resolving surface chemical states in XPS analysis of first row transition metals, oxides and hydroxides: Sc, Ti, V, Cu and Zn, Appl. Surf. Sci., 257, 887-898. 
[24] G.Lu, S.L.Bernasek (2000) Resolving surface chemical states in XPS analysis of first row transition metals, oxides and hydroxides: Sc, Ti, V, Cu and Zn, J. Schwartz, Surf. Sci., 458, 887-898.

[25] S.Wendt, R.Schaub, J.Matthiesen, E.K. Vestergaard, E.Wahlström, M.D.Rasmussen, P. Thostrup, L.M.Molina, E.Lægsgaard, I.Stensgaard, B. Hammer, F.Besenbacher (2005) Oxygen vacancies on $\mathrm{TiO} 2\left(\begin{array}{lll}1 & 1 & 0\end{array}\right)$ and their interaction with $\mathrm{H} 2 \mathrm{O}$ and $\mathrm{O} 2$ : A combined high-resolution STM and DFT study, Surf. Sci., 598, 226-245.

[26] J.Trigueiro, N.Bundaleski, O.M.Teodoro (2018) Monitoring dynamics of different processes on rutile TiO2 (110) surface by following work function change, Vacuum, 152, 327-329.

[27] S.Hashimoto, A.Tanaka (2002) Alteration of Ti $2 p$ XPS spectrum for titanium oxide by low-energy $\mathrm{Ar}$ ion bombardment, Surf. Interface Anal., 34, 262265.

[28] W.Möller, W.Eckstein, J.P.Biersack (1988) Tridynbinary collision simulation of atomic collisions and dynamic composition changes in solids, Comput. Phys. Commun., 51, 355-368.

[29] W.Möller, M.Posselt (2002) TRIDYN_FZR User Manual, Forschungszentrum, Rossendorf, FZR317, Dresden, Germany.

[30] R.Behrisch (1983) Sputtering by Particle Bombardment II: Sputtering of Alloys and Compounds, Electron and Neutron Sputtering, Surface Topography, book, p.179-229.

[31] M.P.Seah, T.S.Nunney (2010) Sputtering yields of compounds using argon ions, J. Phys. D. Appl. Phys., 43(25), 3001-3013.

[32] M.Popović, J.Potočnik, N.Bundaleski, Z. Rakočević (2017) Instrumental function of the SPECS XPS system, Nucl. Instruments Methods Phys. Res. Sect. B Beam Interact., Mater. Atoms, 398, 48-55.
[33] V.Jokanović, B.Čolović, A.T.Petkovska, A. Mraković, B.Jokanović, M.Nenadović, M.Ferrara, I. Nasov (2017) Optical properties of titanium oxide films obtained by cathodic arc plasma deposition, Plasma Sci. Technol., 19, 125504-125513.

[34] V.Jokanovic, M.Ferrara (2020) Mendeley Data, 1 DOI 10.17632/9VXKWWMMGC.1.

[35] P.Eiamchai, P.Chindaudom, A.Pokaipisit, P. Limsuwan (2009) A spectroscopic ellipsometry study of $\mathrm{TiO} 2$ thin films prepared by ion-assisted electron-beam evaporation, Curr. App. Phys., 9, 707-712.

[36] M.Lončarić, J.Sancho-Parramon, H.Zorc (2011) Optical properties of gold island films-a spectroscopic ellipsometry study, Thin Solid Films, 519(9), 2946-2950.

[37] K.Oum, P.W.Lohse, J.R.Klein, O.Flender, M. Scholz, A.Hagfeldt, G.Boschloo, T.Lenzer (2013) Photoinduced ultrafast dynamics of the triphenylamine-based organic sensitizer D35 on TiO 2, ZrO 2 and in acetonitrile, Phys. Chem. Chem. Phys., 15, 3906--3916.

[38] X.F.Song , L.F.Hu , D.H.Li, L.Chen , Q.Q.Sun , P. Zhou, D.W.Zhang (2015) Electrical level of defects in single-layer two-dimensional $\mathrm{TiO} 2$, Scientific Reports, 5, 15989-15995.

[39] A.K.Podshivalova, I.K.Karpov (2007) Thermodynamic analysis of the stability of titanium oxides in the $\mathrm{TiO}-\mathrm{TiO} 2$ range, Russ. J. Inorg. Chem., 52, 1147-1150.

[40] M.M.Abdel-Aziz, I.S.Yahia, L.A.Wahab, M.Fadel, M.A.Afifi (2006) Determination and analysis of dispersive optical constant of $\mathrm{TiO} 2$ and $\mathrm{Ti} 2 \mathrm{O} 3$ thin films, Appl. Surf. Sci., 252, 8163-8170.

[41] N.M.Ravindra, P.Ganapathy, J.Choi (2007) Energy gap-refractive index relations in semiconductorsAn overview, Infrared Phys. Techn., 50, 21-29.

\title{
IZVOD
}

\section{DETALJNA KARAKTERIZACIJA TANKIH FILMOVA NA BAZI Ti-O DOBIJENIH KATODNO LUČNIM ISPARAVANJEM}

\begin{abstract}
Detaljno su analizirana fizičko-hemijska svojstva tankih filmova na bazi titan-oksida, dobijenih katodno-lučnim isparavanjem na površini staklene podloge. Analiza ovih filmova napravljena je primenom XRD, FTIR, SEM, XPS analize i elipsometrije. Na osnovu ovih analiza, posebno analiza koje su dobijene primenom XPS, određena su oksidaciona stanja Ti i identifikovane odgovarajuće faze koje se formiraju unutar različitih slojeve filma od gornje površine do podloge. Dubina različitih faznih slojeva, $i$ njihovi ekstinkcioni koeficijenti i indeksi prelamanja procenjeni su pomoću elipsometrije.
\end{abstract}

KIjučne reči: titanium oksidni tanki filmovi; XRD; FTIR; SEM; XPS; elipsometrija

\section{Naučni rad}

Rad primljen: 22.11.2020.

Rad prihvaćen: 10.12.2020.

Rad je dostupan na sajtu: www.idk.org.rs/casopis

(C) 2021 Authors. Published by Engineering Society for Corrosion. This article is an open access article distributed under the terms and conditions of the Creative Commons Attribution 4.0 International license (https://creativecommons.org/licenses/by/4.0/) 